\title{
The editorial collective and open access: one year on
}

This issue marks the first anniversary of the new format open access Aotearoa New Zealand Social Work journal. Our editorial collective has worked hard to redesign the journal, introduce a new online article submission and reviewing process and promote the journal to local and international audiences.

How we work in the editorial collective is a very collaborative process. Two or three editors work on an issue, managing the peer review process, working with authors and readying the articles for production. Two editors then work on production and proof checking. This spreads the load and means we have a very efficient system in place, enabling us to keep to schedule. Although we operate in a very collective fashion, we decided to appoint an Editor-in-Chief and, towards the end of last year, the collective elected Liz Beddoe to that role for the first three years.

During 2016 we published four issues with 33 original articles, 14 book reviews, one viewpoint and one commentary. These articles, in addition to the issues archived back to 2010, had more than 12,000 downloads during 2016. We have had 4,600 visitors to the journal: $76 \%$ of whom are from New Zealand and 24\% from overseas.

Offering online and open access means we have reduced the barriers to sharing Aotearoa New Zealand social work practice with the international social work community, and many overseas academics and practitioners are choosing to use our journal to publish their research. Using open access means authors, and others, are able to rapidly disseminate their scholarship, research, practice innovation and policy critique using social media such as Facebook and Twitter.
We wish to take the time to thank our international advisory board and our panel of 120 (and growing) peer reviewers, drawn from Aotearoa, Australia, Canada, the United States, Ireland, Hong Kong and the United Kingdom. The strength of a journal lies in its reviewing processes, as our authors attest, good reviews are critical and constructive. As editors, we see our reviewers as vital partners.

Of the four issues published in 2016, two were special issues: one on child protection and neoliberalism, the other on creativity and innovation in social work. We have a publication schedule through to the end of 2018 including issues of Te Komako and Tu Mau. In 2017 we have two general issues planned, a special issue on critical and radical social work and an issue of Te Komako.

Turning now to this first issue for 2017, it is a rich collection of research and scholarship traversing some interesting territories. Some common themes emerge as various articles report research that gives voice to groups whose needs may be overlooked or who have their participation marginalised. Articles draw on qualitative research, literature review, case study and documentary sources and are a good example of the exciting breadth of current scholarly activity of practitioners and academics. The assembled articles traverse a wide set of topics: young people and their experiences as service users and potentially service designers; the transitions of older adults and people with disabilities between forms of independent living and residential care (and vice versa); the history of social work professionalization; the place of counselling in the profession; a critical exploration of the employment of neuroscience in social policy and practice; a
AOTEAROA NEW ZEALAND SOCIAL WORK 29(1), 1-3. 
critique of the internationalisation of student placements; and a discussion of embedded learning activities in professional education.

In Making a claim for services: Supporting young people's engagement with services, Kimberley Dewhurst, Robyn Munford and Jackie Sanders report on a qualitative research project about the factors that facilitate or inhibit young people with complex needs from accessing services. The researchers found that the first critical step was making a claim for services and encountering meaningful responses from service agencies and their practitioners. In this article the voices of the young people tell the story of how warm and positive responses made a difference to service user engagement and to service outcomes.

In Counselling in social work, a legitimate role? Petro Booysen and Barbara Staniforth report research from Aotearoa New Zealand on social workers' use of counselling skills in practice. This qualitative study found that social workers regularly use counselling skills and need opportunities for skill development. The article also addresses the potentially damaging implications of rigid professional boundaries on service users in times of high need. This article builds on the important discussion of counselling in social work by Staniforth (2010).

Following on from the theme of gaining the perspectives of groups with unmet needs, Delia McKenna and Barbara Staniforth discuss the emotional and social needs of older adults transitioning from independent living to residential care. The study Older people moving to residential care in Aotearoa New Zealand: Considerations for social work at practice and policy levels reports that participants wanted greater participation in decision making and more support over the transition period.

Luke Fitzmaurice addresses the topical matter of participation in the formation of social policy in a case study of the inclusion of young people in the work of the Expert
Panel (Modernising Child Youth and Family Expert Panel, 2015). Drawing on his knowledge of the processes of the panel and literature from childhood studies in Children's voices in system reform: A case study on children and young people's participation within the modernisation of Child, Youth and Family, Fitzmaurice makes the case for young people having decision making influence. Careful attention to respecting and valuing children's voices can improve policy and service design.

In a second article, following on from Hunt (2016), Sonya Hunt continues to record the story of social work registration in Aotearoa New Zealand. This article, The social work regulation project in Aotearoa New Zealand, describes the processes which led to the creation of the Social Workers Registration Act (2003) from the 1990s to the initial period of implementation over 2003-4. Hunt traces the influences of many stakeholders in this professionalisation project with a careful collation of documentary sources. Future researcher of the history of social work in Aotearoa New Zealand will be grateful to have this important article to draw on.

In the article by Liz Beddoe and Eileen Joy on Questioning the uncritical acceptance of neuroscience in child and family policy and practice: A review of current challenges to the current doxa, the authors conduct a review of international literature which critiques the influence of neuroscience on social policy and considers this in the context of contemporary policy discourse in Aotearoa New Zealand. Beddoe and Joy argue that one impact of the domination of often dubious claims of "neuroscientism" is the sidelining of structural analysis and social justice in the way the state promotes a very narrow, middle class form of parenting.

International placements have become attractive in social work education bringing benefits of wider opportunities for student experience and building relationships between nations in the global profession. 
But as Ines Zuchowski, Narayan Gopalkrishnan, Julie King, Abraham Francis point out in their critical review, there is potentially a dark side. In Reciprocity in international student exchange: Challenges posed by neo-colonialism and the dominance of the Western voice, the authors explore the phenomenon through a critical lens, recognising the potential for social work education to contribute to a reprise of cultural imperialism and inequitable arrangements, where the Global North partner benefits much more than their counterpart in the Global South. This is an important discussion with significant local and regional relevance as social work education programmes in Australasia forge partnerships in the wider Asia Pacific region.

The second article addressing transitions is A review of adults with disabilities transitioning from their family home to community settings by Garry Lim. Lim reports on a literature review on the transitions of adults with disabilities making the shift between their family home and living in the community with greater independence. The need for significantly better support is noted and a case made for greater government funded assistance in recognition of the potential vulnerability of this group of adults.

The final article by Eva Bowers and Margaret Pack, is Designing and embedding authentic learning opportunities in a social work curriculum: Reflections and lessons learned.
Bowers and Pack discuss an educational project in which filmed scenarios were designed and created to embed into a blended learning programme in social work education. The scenarios in the filmed vignettes were designed to promote critical thinking and to assist social work students to tease out the ethical and cultural issues in everyday practice. With a background framework of Lipsky's street level bureaucracy the vignettes present real life examples of social workers' actions in securing resources and advocacy for service users and the power and authority issues therein.

Taken together, these nine original articles get the 2017 volume of the journal off to a strong start. As editors we know we have many other exciting offerings in the peer review pipeline. As ever, if you are thinking about submitting an article for a future issue, do feel free to approach Liz Beddoe or any other member of the editorial collective.

\section{References}

Hunt, S. (2016). The social work professionalisation project before the 1990s in Aotearoa New Zealand: The dream. Aotearoa New Zealand Social Work, 28(3), 15-25. doi:10.11157/anzswj-vol28iss3id245

Modernising Child Youth and Family Expert Panel. (2016). Expert panel final report: Investing in New Zealand's children and their families. Wellington, New Zealand. Retrieved from https://www.msd.govt.nz/about-msdand-our-work/work-programmes/investing-in-children/

Staniforth, B. (2010). Counselling in social work in Aotearoa New Zealand: The historical, political and socio-cultural evolution. Aotearoa New Zealand Social Work, 22(3), 3-14. doi:http://dx.doi.org/10.11157/anzswj-vol22iss3id179 